Article

\title{
Supporting Children, Blaming Parents: Frontline Providers' Perception of Childhood's Adversity and Parenthood in Indonesia
}

\author{
Clara Siagian*(D), Sandra Arifiani, Putri Amanda and Santi Kusumaningrum \\ Center on Child Protection and Wellbeing (PUSKAPA), FISIP University of Indonesia, Jawa Barat 16424, \\ Indonesia; sandradewi@puskapa.org (S.A.); putriamanda@puskapa.org (P.A.); santikn@puskapa.org (S.K.) \\ * Correspondence: clarasiagian@puskapa.org
}

Received: 31 October 2018; Accepted: 15 February 2019; Published: 20 February 2019

\begin{abstract}
This article explores the construction of childhood and parenthood in rural communities in Indonesia based on a series of focus group discussions with service providers, community decision makers, and paraprofessionals; a group that we refer to as "frontline providers". By examining the providers' definition of successful children and their perception of factors that could undermine a child's success, we provide insights into how frontline providers understand the role of parents, and how parenthood is constructed accordingly. We found that the providers' definition of successful children reflects a strong neoliberal logic and that education is seen as the primary mechanism of such investment, an evolution of the idea of a modern nation under the previous regime that has permeated into an individual assessment. The paternalistic culture has further cemented the tendency among the frontline providers to problematize parents as the main risk factor for children's educational achievement and to ignore the structural and ecological factors. We traced this paradigm in Indonesia's educational and child protection policy framework, prompting a myriad of parenting programs that put parents from the underprivileged group as the main subject of intervention. Informed by studies in different countries, we argue that without changes in structural factors, any intervention on parenting will be deemed ineffective.
\end{abstract}

Keywords: childhood; adversity; neoliberalism; parenthood; education; Indonesia; child protection; parenting

\section{Introduction}

There is a growing recognition that childhood is a constructed concept shaped by social, political, and economic contexts and factors (James 1997; Qvortrup 2008; Tesar et al. 2016). Investigations into the contemporary discourse on childhood show that education is widely accepted as the prominent feature of a child's life (Boyden 2013; Wells 2009). As Qvortrup (2008) argues, childhood has become a period of life in which the sole objective is to train children to become functioning adults. The prolongation of childhood is marked by the extension of compulsory education that coincides with or even extends beyond, the common legal age of childhood (Wells 2009). In his intergenerational longitudinal study on childhood in central Java, White (2012) finds that school has become a legitimate use of children's time and that parents believe education is essential for children; in fact, White did not find a reduction in school enrolment among his respondents during the economic crisis (White 2012).

The construction of childhood, however, does not occur in a vacuum. It goes hand-in-hand with the construction of parenthood, reflecting what Ambert (1994, p. 530) previously observed as "where one sees children, one 'sees' parents. When one sees children who have problems, one looks for parents, especially mothers". This intersection of the construction of childhood and parenthood has 
drawn substantial scholarly interests in developed countries (Davies and Bansel 2007; Gillies 2005; Holloway and Pimlott-Wilson 2014; Hyslop et al. 2018; Peterson et al. 2011; Russell et al. 2008). These studies suggest an alignment of childhood and parenthood with the neoliberal paradigm that emphasizes parental responsibility in children's educational achievement. Children at risk are increasingly identified by assessing their parents' characteristics, parenting style and capacities. There are increasing attempts from the government to standardize parenting practices, and to incentivize parents to behave accordingly, a notion that's widely shared by educators and social workers in developed countries.

However, research has only just started exploring these relationships in developing country contexts. This study extends the body of literature by providing insights from rural communities in the developing country, Indonesia. In Indonesia, there is a growing number of studies that seek to build evidence to improve children's wellbeing (see Suryadarma and Jones 2013; O'Kane and Lubis 2016; Sumner and Kusumaningrum 2014; Kathryn 2015; UNICEF 2017). Nevertheless, there is still limited evidence about how the population perceives the twin concepts of childhood and parenthood, and how the two are intertwined in the context of Indonesia.

Drawing from a series of Focus Group Discussions (FGDs) in rural communities in West Sulawesi, Indonesia. This study fills this gap by exploring how childhood adversity is understood by service providers and paraprofessionals who provide immediate services to children and families in the community; a group that we refer to as "frontline providers", following the term used by Pepinsky, Pierskalla, and Sacks (Pepinsky et al. 2017). We believe that frontline providers hold a central role in putting policies into effect through their interpretation of the policies. Therefore, an examination into frontline provider's perception, a predisposition towards child wellbeing, and the role of parents is important to give insights into the process of manifesting relevant policies on children into action. Furthermore, frontline providers, by virtue of their training and positions, represent the middle-class and its values that significantly influence the way the poor class is considered, problematized, and governed. We further our analysis by assessing the relevant policy framework and comparing it with the frontline providers' understanding. By doing this, we explore the permeation of neoliberal ideas in the construction of parenthood in a rural community in Indonesia and how it could be understood by situating it within the socio-historical context of Indonesian society. Participants' aspirations echo a remnant of developmentalim and modernization discourse that was prevalent under the Soeharto era, and idealizes industrial-urban life over agrarian life.

\section{Research Setting and Methods}

This study took place in six villages across three districts in one province, West Sulawesi. The provincial site was purposively selected through consultation with the Ministry of Education (MoEC) and Culture and Ministry of National Development Planning (BAPPENAS) using educational outcomes as the main criteria for selection, primarily focusing on areas with lower outcomes. Data collection was conducted in October 2016 as part of a larger exploratory study to understand and design socially and culturally appropriate longitudinal survey instruments on child wellbeing. This paper is based on the secondary analysis of FGDs conducted with a mix of service providers and paraprofessionals who interacted directly with children and parents in their daily public roles; we hereafter refer to this group as "frontline providers". Frontline providers consist of professional service providers, such as teachers, midwives, and social workers; community decision-makers, including village chiefs and administrators; and community paraprofessionals, such as paralegals, health cadres, and volunteers. Respondents generally came from the middle-class in the communities visited, and many respondents were parents themselves. The FGDs followed a semi-structured process and usually covered three to four broad topics. The data used in the present analysis includes responses from the first half of the FGDS, during which facilitators asked participants how they would define children and successful children. Once the parameters of successful children were discussed, 
respondents were asked to consider the factors that adversely impact children. Data are available upon request from the authors and their corresponding institutions.

In total, researchers conducted 11 FGDs in three districts with a total of 106 frontline providers (Table 1). All participants were informed of the study objective and consented to participate. FGDs lasted between one and two hours. No monetary reward was given for participation, although meals and drinks were provided during the FGDs. All FGDs were facilitated by one male and one female researcher; one researcher served as the leader of the discussion, and the other took notes. All researchers and note takers were native speakers of Bahasa Indonesia and participated in a two-day training that covered the objectives, structure, and instruments for the main study. All FGDs were audio-recorded and transcribed. Transcripts were analyzed using a thematic analysis method (Guest et al. 2011) informed by the interpretive approach (Hendriks 2007; Yanow 2000). Transcripts and quotes from participants were treated as the "text" for the interpretation of meaning. The first author carried out the initial identification of themes, and subsequent refinements were conducted by all authors through the discussion of disagreements and tracing the relationship between themes. The FGDs and analysis were conducted in Bahasa Indonesia. Policy documents were analyzed by applying the themes identified from the FGDs using the same interpretive approach.

Table 1. Details of Focus Group Discussions (FGDs), location and participants.

\begin{tabular}{ccccc}
\hline Location (Districts) & Number of FGDs & Male & Female & Total Numbers of Participants \\
\hline Mamuju & 4 & 19 & 16 & 35 \\
Mamuju Tengah & 4 & 20 & 26 & 46 \\
Mamasa & 3 & 10 & 15 & 25 \\
\hline
\end{tabular}

\section{Contextual Background}

\subsection{The Trajectory of Neoliberalism in Indonesia}

The themes presented in this paper rely on an understanding of several key concepts, including neoliberalism and the social construction of childhood in Indonesia. While an extensive discussion of the debate on neoliberal trajectories and the evolution of childhood in Indonesia is beyond the scope of this paper, we consider them here in brief. In summarizing the concepts for this paper, we organized the debate into two main categories: under Soeharto's regime (1966 to 1998) and post-Soeharto (1998 to present). We are aware that in doing so, we risk generalizing an era that spans 52 years. When it is important to the discussion, we note the specific administration or period for the events.

Neoliberalism is often understood as an economic principle that believes in individual freedom and entrepreneurship to operate in a free market as a way to advance the wellbeing and to flourish a society (Soss et al. 2009; Harvey 2007). Although both advocates for a free market, neoliberalism differs from a liberal perspective. While liberalism wants to limit the state's intervention on the market and individuals, neoliberalism warrants a strong state to enforce the market principle into all aspects of public affairs, and to promote certain behaviors in individuals to thrive in the free market (Soss et al. 2009). Although the society is presented as a free market of opportunities, these opportunities are only accessible to everyone with an entrepreneurial spirit, competitiveness, ability to demonstrate self-discipline, and industrialized attitudes (Soss et al. 2009; Gillies 2005; Mccafferty 2010; Davies and Bansel 2007). As such, neoliberalism as a doctrine and set of practices has successfully permeated into different aspects of governance (Harvey 2007).

There is burgeoning literature based on neoliberalism in Indonesia, particularly concerning economic development (Shiraishi 2006; Liddle 1996) and how it subsequently affected the political realm (Hadiz 2004; Robison and Hadiz 2004; Aspinall 2013). Indonesia's history is characterized by an uneasy embrace of market-oriented economic principles, a legacy of Soekarno's ardent rejection against neoliberal economists (Chandra 2011). Under Soeharto, Indonesia entered a developmental phase focused on achieving financial stability and improving macro-infrastructure, led by an elite 
group of US-trained economists who comprised the core component of the National Planning Agency or Bappenas (Shiraishi 2006).

Nevertheless, under Soeharto, neoliberal ideology was contained within the realm of economics; the ideology did not transform into a system of values that permeated other public domains. The political dimension was characterised by pervasive patronage, clientelism, and rent-seeking, perpetuated by Soeharto for his maintenance of power (Robison and Hadiz 2004; Blunt et al. 2012). The strong influence of patronage politics and the rent-seekers often forced neoliberal economists to frequently compromise the political interests of Soeharto's cronies, including the military (Shiraishi 2006). Furthermore, due to strong paternalistic culture, there was no strong emphasis on individualism. Instead, Soeharto continued to valorize the rhetoric of national collectivism and gotong-royong, or working together as a family, as the nation's ultimate objectives (Li 2005). Individual and sub-group identities and interests were undermined in the name of unity, and national identity (Heryanto 1995) and the central regime managed to govern the community under the pretense of a self-reliant community (Newberry 2014b).

\subsection{Paternalism and the Rhetoric of Family in Indonesia}

In order to more clearly understand the trajectory of neoliberalism in Indonesia during Soeharto, it is important also to understand the role paternalism played in the development process. Development under Soeharto was interpreted as a project to modernize the nation by civilizing parts of the population that were considered backward, traditional or "kampungan," and unsophisticated (White 2005; Newberry 2014a; Li 1999). Development was equated with modernization, or the process of moving from subsistence to an industrialized society (Heryanto 1995). This specific image of a developed nation was insidiously and successfully promoted by the state through textbooks, school curriculum, popular media, and special indoctrination for civil servants (Parker 2002; Kitley 1999; Warouw 2004; Moser 2010).

Paternalism is used to describe an unequal relationship where an authoritative entity prescribes specific actions and behaviours onto its subject, due to its perceived superior knowledge about what is best for its subject. Paternalism is reminiscent of a parent-child relationship where the parent, typically the father, is understood to know the best interests of the child (Gibbon et al. 2014; Soss et al. 2009). During Soeharto's period, paternalistic culture in bureaucracy successfully served the interests of the developmentalist state. The state took the role as the benevolent father by proxy of its elite technocrats and street-level bureaucrats, whereas poor agrarian villagers and remote ethnic groups assumed the position of the child. Soeharto was portrayed and imagined as the "father" for the citizens or the nations (Newberry 2010). If men were positioned to lead within the formal administrative structure, women or wives were organized into quasi-public groups with the responsibility to manage domestic affairs as their contribution to the social reproduction (Newberry 2010). Furthermore, many modernist-developmental programs of the state were conducted at the grassroots level by the voluntary services of housewives and women's organizations, particularly programs for the family, such as family planning and child healthcare (Newberry 2010).

\subsection{Neoliberalism in Indonesia after Soeharto's Regime}

The post-Soeharto era marked a shift in authoritarian development in Indonesia. What followed was a period of consolidation of political power and the deepening of economic neo-liberalization. The succeeding administration had few options but to implement packages of economic adjustments offered by the International Monetary Fund (Chandra 2011). Once macroeconomic stability was achieved, the government could focus on poverty alleviation and infrastructure programs with strong support from the World Bank, other bilateral aid agencies, and opening up the market to foreign investments (Adriany 2018; Chandra 2011). The state's development efforts also saw significant changes.

The first change was the heavy involvement of international aid agencies that enabled the penetration of neoliberal concepts such as good governance, empowerment, and community-driven 
participation, directly into a local level (Li 2005; Chandra 2011). The penetration was also facilitated by the decentralization of power to the district level and as per the conditions of the aid packages (Li 2005). Second, at the activity level, there was and still is a massive mobilization of civil society organizations and NGOs to provide capacity-building for individuals aligned with the types of capital one needs to survive in the market (Newberry 2010). While poor communities remain the target of government interventions, these interventions are now directed at the individual level (Gellert 2015). As such, paternalism has been able to adapt to Indonesia's new decentralized and democratic governance (Blunt et al. 2012; Warouw 2004).

\subsection{The Construction of Childhood in Indonesia}

The third development difference between Soeharto's and post-Soeharto's era of relevance to this paper can be observed within the construction of childhood and parenthood. During the New Order, the idea of childhood was shaped by the Javanese concept of family that centralizes the father as the authoritative figure and children as the subordinates who obey their parents (Shiraishi 1996). This concept of family and children was compatible with the state's paternalistic approach toward development and the imagination of the nation as a family. With the introduction of universal basic education, the New Order government was able to extend the concept of a nation as a family by establishing the hierarchy between teacher as parent and student as child. Through a myriad of school activities such as the flag ceremony, children were taught to subvert their individual characteristics and preferences and to view themselves as part of the uniformed nation-family with an obligation to contribute to development (Shiraishi 1997, 1996)

After the New Order and the beginning of the decentralization era, the concept of childhood in Indonesia was gradually changed as the global discourse on childhood began to enter the national policy agenda. Since the stipulation of the Child Protection Law in 2002 that codifies Indonesia's adoption of the UN Convention on the Rights of the Child, children are no longer solely seen as the subject of their parents' authority, but also as individuals with inalienable rights to protection, as well as participation in public life. These changes afford the state a stronger license to intervene in the family and veto parents to ensure the best interests of the child. The strong influence of international aid regimes has also contributed to ensuring that a child's "best interests" are measurable, expert-driven, and middle-class oriented (Newberry 2010).

Education is not only the mechanism through which the state instils national values and collective identity, but it has also evolved to become the main process through which children are prepared to become entrepreneurial and competitive individuals (Silalahi et al. 2018). Since 2002, the government legally committed to spending 20 per cent of the national budget on education (Suryadarma and Jones 2013). Inspired by the movement of evidence-based policies, childhood is increasingly professionalized, and children are subject to more universal indicators and technical programs as the government binds itself to several global development commitments, most notably, the Millennium Development Goals and currently, the Sustainable Development Goals (UNICEF 2017).

The human rights discourse has also changed the way parenthood is defined. The Child Protection Law has couched the parent-child relationship within the "rights" lexicon. The parent-child relationship is no longer characterised by parents' authority over their children but by parents as holding the obligation to provide for their children's health and development, education, and, protection. Parents are duty-bound to raise children healthily, to cultivate their child's potential, to educate, and to prevent early marriage. However, the Law also retains some aspects of the previous rhetoric on family and collectivism by balancing children's rights with a duty to respect parents and teachers and to love the nation. Some programs dedicated to children still utilize the modus operandi of community organizing under Soeharto's era, for instance, by taking advantage of women's voluntary labour (Newberry 2010). 


\section{Research Findings}

Before delving into the findings, it is important to note that during FGDs, participants' roles as frontline providers and parents were intertwined and inseparable. Their perceptions and opinions are strongly influenced by their various roles in the community and by their own experiences as parents, and to a lesser extent, by reflection on their own childhoods.

\subsection{Successful Children Are Economically Independent Adults}

Participants' definition of successful children overwhelmingly focuses on a child's orientation as a future adult. There is notably only one participant who defines a successful child as being one who is happy and could make others happy at any given age, regardless of their financial, marital, and employment status. The dominant perspective among participants, however, is to determine a child's success based on his or her socio-economic status when they reach adulthood. The majority of participants point to economic self-reliance and employability as the main parameters for identifying a successful child. Children are expected to grow up into financially independent adults:

"If the child has his/her motorcycle, that's not a success. Success is when a child can continue their parent's job, complete education, and has [a] job and income; that is a success".

For some participants, financial autonomy takes the form of acquiring a good, and if possible prestigious, job. Since livelihood precariousness is a dominant feature of life in West Sulawesi-including for many of the participants—success is also equated with job security.

The aspiration for upward mobility is made even clearer by parents' stated preference to marry off their daughters to men of success. Children are considered successful if they marry successful partners; for girls, this means marrying a wealthy husband, or at the very least, a person with a steady job. Although one participant notes that due to increasing schooling opportunities, many girls are now marrying later, other participants argue that gender differences in parents' aspiration are far from gone:

"So, there are differences between girls and boys, especially parents' expectation and hopes. Boys are expected to be a great man (success), whereas, the girls, and I'm sorry to say this, but the parents usually say this to their daughters, 'hopefully you will find a great and steady husband'. Just like that".

Nevertheless, later in the discussion, some participants highlight the stubborn practice of child marriage in their community. Although Indonesia has come a long way in reducing the incidence of child marriage, it still has one of the highest rates of child marriage in the region, with 1 out of 6 girls estimated to marry before 18 years old (BPS and UNICEF 2016). Girls in rural areas are more vulnerable to early marriage due to a number of factors including strong patriarchal norms, a lack of educational and employment opportunities, and economic motivation (Bennett 2015; BPS and UNICEF 2016), as suggested by one participant:

"It's parents' low education primarily. That's why when they see that their children find a suitor, they choose to marry their children or if their daughter gets pregnant, or even if that's not the case, once the children are dating, they must get married".

The majority of the participants reference the attainment of an education as a criterion of success. Many participants expect children not only to complete compulsory education but also to graduate from college or university. This view, or perhaps aspiration, for children to have a higher degree, sometimes seems to be informed by the participants' lower educational achievement. As one participant says,

"If I must be honest, I am only graduated from elementary school because my parent could not afford to send me to school. Therefore, I want to support my child's education, hopefully to university". 
More importantly, however, education is strongly considered to be the principal means for achieving a job and financial stability. Participants mention several benefits of education for children, including the accumulation of knowledge, higher personal aspiration, better financial management skills, and the acquisition of marketable skills. Participants agree that the higher the education a child can attain, the better their prospects will be for securing a formal and profitable livelihood. Without the specific skills one can acquire through formal education alone; participants conclude that a child could only work as a laborer in backbreaking jobs.

"I have colleagues at work; they were only graduated from junior high school. What they can do is just carrying sand and stones [in construction projects]. Maybe because even if they want to find a job outside [the village], it's difficult. It's hard for them to find a job because they lack special skill".

"Of course. I gave [the children] motivation and said that 'if you are going to school, you can be like this or like that but if you are not going to school, you will stay like this, you'll just become a farmer'."

A small number of participants mention other normative aspects of success, such as being pious, being obedient to elders, and making a positive contribution to families and communities. The social contribution is defined by being able to create jobs for other people. This indicator of success is perhaps an echo of the perception of children as the nation's future.

"Parent's expectations are met if the child has succeeded, for instance, when the child leaves to find a job and get an income to fulfil their parents need. That's a success".

"A successful child is like the one who reaches a bachelor degree. Well, that's our dreams. For me, a developed nation must have a generation that can compete and are innovative. In turn, they can create employment for others to be independent".

\subsection{Irresponsible Parents Prevent Children from Becoming Successful}

Since success in this context predominantly refers to employment and financial security, and education is regarded as the essential means to achieve this success, it is unsurprising to learn that participants' conceptualization of childhood adversities are directly and indirectly related to schooling. Through discussions with participants, it is apparent that parents are seen as playing a central role in childhood adversity while other actors, such as state and communities, play a comparatively peripheral role.

Participants note that parents have the potential to become a detrimental factor in a child's educational achievement through certain attitudes and attributes. Participants speak of several parental attitudes that might become prejudicial to a child's future. Some participants use parents' views on education as an indicator to assess whether or not the parents have a progressive outlook. Parents with a low valuation of education are regarded by the participants as a critical barrier to children achieving a higher education:

"My conclusion is such: urban parents, well they're fortunate, they have modern forward thinking. They know that if children go to school, they will get good jobs. But for our people here, such thinking is still beyond them. They never realise that it is a high level of education that leads to better jobs".

"Well basically, from parents' perspective, they regard that, 'whether you [the child] want to go to school or not, it is your own business, as long as you can work and provide income'. That's how our parents here think".

The New Order's developmentalist discourse is evident in the way participants categorize parents and idealize the modern family that was promoted through popular media and schools' textbooks. These conceptualizations align parents of urban communities with modern thinking, while parents from rural communities are denounced for their backward mindset. Parents who work in industrial sectors are idealized and contrasted with parents who work as farmers. Education is once again a primary theme in these discussions, with parents' lack of education used to explain their 
precarious livelihood situation and, consequently, their lower income level and inability to provide for their children.

"But Mamasa has a different version. Here, I may categorize many children as neglected. Why? Because the children don't have their rights fully met. But, it is not intentional. It is because of economic factor. In general, aside from public servants and businessman who have a steady income, most parents don't have a steady income and tend to rely their livelihood on farming".

Concerning child marriage, several participants assert that parents' low education, along with social pressures, contribute to a high number of children dropping out from schools due to marriage.

"It's parents' low education primarily. That's why when they see that their children find a suitor, they choose to marry their children or if their daughter gets pregnant, or even if that's not the case, once the children are dating, they must get married".

For many participants, parents' attributes such as a lack of education and inferior economic status justify some of their disadvantageous parenting behaviours. For instance, participants argue that parents' limited schooling contribute to their lack of awareness, knowledge, and practice around "good" child care.

"According to my observation, the relationship between parents and children is quite harmonious.

But I observed that perhaps because their low level of education and their livelihood as farmers, some even never went to school, their participation in their children's health and education is also low".

Parents are not only judged based on their regards to children's education, but also with respect to their parenting styles. This suggests a weakening of parental authority in the process of raising children. One participant, for instance, complained about certain parents' lack of assertiveness to keep their children in school, while another laments about parents who use physical violence to discipline their children at home. This parenting style, she argues, "will deeply traumatize children and lead to disrespect toward parents and anti-social behaviours". Parents' disadvantaged backgrounds, particularly low education levels and precarious livelihoods, are often put forward to explain their lack of a capacity to better care for their children. Many participants comment negatively on the way some parents interact with their children.

"[T]he interaction between parents and children are limited because the parents are so busy with farming. On average, parents will spend their daytime in the field, and they're back at home when their children [are] already asleep. Therefore, they don't have time to have interact".

Parents' disregard toward education and their harsh disciplining tactics are said to cancel out teachers' efforts in educating children in schools. Other participants also express disapproval towards parents who openly whine in front of their children:

"The teachers in the formal school have done their responsibility to educate the children. But if the children live in the family with low awareness and concerns on education or temperamental parents, the violence and abuse that parents use to educate will influence [the children]".

"Maybe [it'd be better] if internally, in the family, parents can stop complaining. If the children hear their parents grumbling, they will immediately get depressed. Because, many parents cannot control their emotion, right?"

Mothers are often singled out, particularly when the discussions delve into children's health and nutritional status. For instance, mothers are blamed for choosing traditional birth delivery over medical practices.

"The next issue is the lack of mothers' understanding of nutrition and public health. I can prove that there are still many mothers who prefer to deliver with a traditional birth attendant to health facilities. Although the government has conducted sensitization and provide free health services, the people assume that the quality of free health service is low while going to the doctor is rather expensive". 
The topic of higher education is frequently mentioned during sessions, suggesting an increased educational expectation for children in the community. Participants assert that parents with lower educational attainment are ignorant and lack a willingness to motivate their children to continue to higher education. In the eyes of the participants, these parents have failed to become a good role model in regards to academic achievement; as one participant says, "there's a correlation. If the parent's education in below junior high school, the child will be unmotivated to continue school above that level".

"Many children don't know what they want to do after completing school. So many of them don't feel like continuing school. They don't know which faculty they prefer or what they want to become.

There's no motivation and expectations from the parents that could help the children to find direction".

Parents are blamed for failing to supervise and discipline their children. This lack of parental control is often attributed to unconventional family arrangements. Some participants point to separation, migration, and remarriage as precursors to children's neglect or children being taken care of by their grandparents or extended families. Transnational migration, mainly prompted by the need to earn better incomes elsewhere, often leads to family separation (Pye et al. 2012). The divorce rate has also increased since 1995; especially due to the increased education and empowerment among women, and the growing acceptance over a woman's decision to end her marriage (Cammack and Heaton 2011).

"Most of our children here are orphans because both or one of their parents died. We also have children here victims of their parents' divorce. Both of their parents remarried and lived with their new spouse and family. These children are still in elementary school age, and their irresponsible parents abandon their responsibilities".

Parents are depicted as both unable and unwilling to prevent children to work and to keep them in schools. Some participants accuse some parents of being ignorant about their children's education, while others offer a more sympathetic assessment, arguing that poor parents are forced into this viewpoint by their economic condition.

"Commonly, they are trained to earn money. School may be the second [priority], after earning money and getting married".

"It similar with your opinion, ma'am. I mean, especially it happens in Karampuang [a village in West Sulawesi]. We see parents ask their children who just finished elementary school to work, perhaps due to economic factor".

\subsection{The Noble State and the Missing Community}

Conversations with participants paint a picture of a childhood that is marred with multiple deficiencies. Participants see parents, and their failure to parent, as the most significant factor in impeding a child's success. Other actors, such as the state, professionals working with children, the private sector, and the community as a group are given less significance.

Paternalism remains the dominant attitude among the frontline providers, as evidenced by the way participants contrast the government's efforts with parents' personal inadequacies. The government is lauded as a good benefactor and provider, resembling the image of the benevolent father that was promoted during Soeharto's era. For instance, a few participants opine that the government has invested a massive amount of money in building school and health facilities, as well as various cash and in-kind transfers that aim to help families in caring for their children. The state is thought to have spent much effort in providing free education: "It is a great fortune befall on us and our children", remarked one participant, "where previously we couldn't go to university, now at the sub-district level, we have two even three senior high schools".

Parents' ignorance toward children's educational attainment is deemed inexcusable given the increase in schools providing education free of charge. 
"Here, there are so many assistances in this area; even the education is rarely charged. When I visited Karampuang and other areas in Mamuju, the school is free; even the children receive uniforms. They are given everything. But, again, we must work still because parents don't care about it. The economy might've been an obstacle for children to go to school, but I don't think that's the case anymore. I can say this because the government has provided everything for free".

Only a few participants raise the quality of education in schools as an issue that could prevent children from achieving success. One participant points to teachers' motivation and teaching methods as particular problems; a few participants highlight the meagre remuneration given to teachers.

Parents are blamed for their backward mindset, as well as a lack of knowledge and awareness, rendering the facilities and programs aimed at helping parents avoid redundancy. Families are accused of being resistant to behavior changes and having no motivation to be economically self-reliant. Some participants insist that no amount of information dissemination could make up for parents' lack of awareness.

"Oh, there are already so many supports from the government. Please note this and tell the national government that the problem is the community is too spoiled. For this ongoing activity, we have to ride motorbikes through an uphill road, sometimes in the rain. But the community doesn't want to be educated because their mindset is only about money. That government assistance is only about cash".

In regards to the increasing number of direct transfers from the state to families, a few participants argue that cash transfers wouldn't help children if their parents don't improve their parenting style. Furthermore, parents are denounced for misusing the cash for non-schooling consumption.

"At the senior high level, many children don't continue because of the economic factor. The government already provides BSM [scholarship for poor students], but the awareness about BSM is still low. The $B S M$ is for school, but many beneficiaries use BSM money for their personal needs. Even to use that money to purchase shoes is already a form of violation".

Participants' grievances related to government services rarely extend beyond physical and programmatic barriers to accessing education, or health services to a lesser extent. The main complaint given is the distance to schools, especially to secondary school level and higher. As public transportation is virtually absent in many remote communities and the government doesn't provide school transportation, families have to arrange their own transportation, mostly through motorbike purchases. When discussing government programs, participants tend to focus more on issues with implementation, rather than program objectives. For example, participants reference issues with inaccurate data, and inadequate supervision and coordination.

Notably missing from the conversation is the role of community in raising children. This gap in the discussions contrasts the discourse of harmonious communal life perpetuated by the New Order regime (Kitley 1999). When a few participants do mention community, its role is vaguely defined. In a few notable conversations, participants assign the community-and particularly customary and religious institutions - the role of controller. Cultural and religious norms often take precedence over legal avenues when there is a conflict within and between families. As such, the main role of traditional governance, in the view of participants, is to maintain social harmony.

Many participants note they rarely relied on their neighbors, and conversely, that they rarely involve themselves in their neighbors' family life. One participant remarks that "communal responsibility is in decline and everyone is only thinking about themselves".

When mentioned, the role of neighbors in assisting parents in childcare is deemed mostly marginal. Neighbors are said to help during medical emergencies. The previously heralded notion of gotong-royong is narrowly depicted as the community gathered together to clean their village. Neighbouring mothers sometimes engage in information sharing about nutrition, whereas religious figures sometimes use their position to raise awareness and educate parents. The lack of concrete support provided by the community for parents' daily struggles is illustrated by this exchange: 
F: Did the community ever do something to solve this [lack of parents' economic power]?

$R$ : They give motivation for children, for sure.

F: Did the community, for instance, financially support a kid whose family experiences harvest failure or unemployment?

R: We only help each other in farm labors.

Individualism is thought to underpin the lack of communal cooperation in raising children. When asked if there is a sense of communal responsibility to help families raise their children, one participant remarks, "I think we don't have that. Some parents are offended, if we intervene". The individual family is left to its own devices in addressing both internal and external issues. However, cases of extreme neglect or physical abuse seem to be the limit to a family's autonomy, with one participant noting that "When I see my neighbor's children get abused or badly treated, it is my responsibility to warn or rebuke it, Sir".

\section{Discussion}

The narrative that emerges about successful children from these FGDs suggests that children are mainly important due to their potential to become adults (Qvortrup 2008; Wells 2009). The participants' main conception of successful children echoes the current understanding where childhood is seen as a period of training, in which the final assessment culminates during adulthood (Qvortrup 2008). However, this definition of successful children does not necessarily imply a certain way to value children but rather, as we argue later, as a way to assess parents.

The subscription to neoliberal ideas in defining childhood success is evidenced by the way the participants defined accomplishment in various socio-economic aspects, such as employability and financial autonomy. In a society such as Indonesia, where many provisions of needs are accessed through the market, having a job that provides a steady stream of income is crucial for survival. From the neoliberal perspective, citizens are expected to govern their conducts, such as being competitive and entrepreneurial, to become economically self-reliant in the market (Cradock 2007; Davies and Bansel 2007; Mccafferty 2010). The participants' aspiration to have children who grow up to be highly educated, earn a high income, and marry richer partners could also be understood as remnants of the modernization discourse under Soeharto that promoted the image of an urbanized and industrialized nation (Li 1999). This specific image of modern society has now permeated into how children, and thus their parents, are being assessed by service providers.

The participants' aspiration for children to become economically affluent is aligned with findings from other developing countries (Boyden 2013; Crivello and Boyden 2012) but stand in contrast with the findings from a developed country (Holloway and Pimlott-Wilson 2011). Poor parents in Peru, India, and Vietnam aspired to send their children to schools so they could find jobs with better income. Meanwhile, Holloway and Pimlott-Wilson's study in low-income Anglo-Saxon neighborhoods in the UK found that low-income parents mostly wanted their children to be happy and behave well (Holloway and Pimlott-Wilson 2011).

\subsection{Education as a Ticket for Employability}

The findings strongly suggest there has been a shift from the New Order education-based objective-where children are collectively conditioned to be patriotic citizens-to a new approach, where children receive education as preparation for work. In the New Order, children were seen as apprentice citizens who needed to be socialized into collective values through schooling. In contrast, under the neoliberal regime, children are regarded as a human capital investment; childhood is seen as a period to invest, and education is therefore seen as the primary mechanism of investment.

Among poor families, education is not only considered as the end but also overwhelmingly as the means to escape the precariousness and deprivation of poor rural lives (Boyden 2013; Crivello and Boyden 2012; White 2012). According to participants in this study, the higher level of education a child obtained, the better chance they had of improving their life, either through acquiring a well-paying 
job and/or marrying a good partner. Sending children to higher education has become the normative expectation imposed on parents, as evidenced by participants' concerns about parents who failed to support their children in attending university.

In the context of childhood, education has arguably become the "most defining feature of modern childhood" (Boyden 2013; Wells 2009). The participants' faith in education is an extension of the subscription to the neoliberal approach to education as a way to improve human capital, thus expanding the market efficiency (Adriany 2018; Mccafferty 2010). The education system, with schools, teachers, and standardized tests as its tools, claims to produce merit citizens with an entrepreneurial spirit that would thrive in the market-based society (Davies and Bansel 2007; Mccafferty 2010). The standardized test, one of the main features of neoliberal education, provides an illusion of a merit-based institution where an individual's hard work in school meets its fair reward.

Most participants readily equated one's level of education with the kind of job that can be accessed. For the participants, education is predominantly important through its provision of the formal recognition of one's educational status with a diploma, with some stressing the importance of having a university degree as a bare minimum to apply for formal employment. Little discussion occurred around the quality of education and the specific skills that are demanded by the current labor market and whether or not the education system equitably teaches them. As suggested by Boyden (2013), this rudimentary expectation of education might be explained by parents' own limited experience in the education system (see also Holloway and Pimlott-Wilson 2011).

This unconditional support of the education system might be seen as problematic when the education system fails to challenge the social reproduction of class and inequality. Scholars have argued that the current education system is the very machinery that maintains social stratification and prevents social mobility between classes (Ling 2015; Tomanović 2004; Wells 2009). Marginalized children tend to go to schools of lower quality and, even if they do attend top schools, they and their parents lack the social and cultural capital essential for exploiting the opportunities in school and beyond (Reay 2004; Tomanović 2004). In Indonesia, there is still a significant difference in educational outcomes between poor and affluent students. Analysis of PISA score of 2009 shows that children from low-income families in Indonesia perform much lower than average students both in mathematics and reading (Al-Samarrai and Cerdan-Infantes 2013, p. 120). Furthermore, an analysis of the Indonesian socio-economic survey of 2009 demonstrates that the enrolment rate for the senior secondary school in the poorest quintile is 29 percent, compared to 73 percent in the richest quintile (Suharti 2013, p. 35).

\subsection{All Blames Lead to Parents}

The participants in our study contended that education is in "the best interest of the child" and, when children fail to achieve their best, optics are placed on parents. Parents, or deficient parents, were identified by participants as the main risk factor for children's low educational achievement. In contrast, the state and community were mentioned infrequently in this context. The state is seen as a good, although not perfect, enabler for children to flourish. Participants' references to ecological factors, such as employment conditions, were always framed as parents' shortcomings, suggesting a transformation of a structural problem into an individual issue (Hyslop et al. 2018; Russell et al. 2008).

Instead of talking about poverty as a marginalizing force, the participants focused on poor parents instead; the linguistic distinction is non-trivial. Since structural factors are mediated through parents, most of the participants' proposals for interventions were directed toward parents and families. When economic issues were raised in FGDs, especially in regards to precarious livelihoods, none of the participants expressed a desire for the government to improve labour or agriculture policies. They instead asserted it was the responsibility of parents to take advantage of the improved services that the state has provided, despite the problem on accessibility and quality of services. In the findings, the frontline providers blame mothers for choosing traditional birth delivery over medical practices, while research has revealed that traditional birth attendants are chosen because they are often more accessible than health services in some parts of Indonesia, and they are considered more experienced 
and more trustworthy since they share the same culture with their clients (Titaley et al. 2010). When the participants denounced the children, it was framed as a reflection of parents' failure to discipline and to motivate their offspring (Walters and Woodward 2007). Parents whose children fail to excel in school are deemed as incompetent, uncaring, and ignorant. These parents, according to frontline providers, should be trained in how to better care for their children.

The construct of parental blame can be found in countries from both the global south and north, particularly among educators and social workers. Education professionals contend that parental aspirations are low because parents do not conform to normative expectations of higher academic and labour market success (Holloway and Pimlott-Wilson 2011; Peterson et al. 2011). Social workers, for instance, tend to emphasize deviance, dysfunction, and incompetence in parenting when assessing child protection cases (Hennum 2014; Hyslop et al. 2018; McConnell and Llewellyn 2005). Educators and social workers frequently intervene based on their perception of parental failures. In high-income countries, protection workers more often suggest the removal of children from home rather than the provision of support for families, without exploring other alternative solutions, ensuring that both interventions have limited success (Hyslop et al. 2018; McConnell and Llewellyn 2005; Walters and Woodward 2007).

Participants' preoccupation with parents, the shortsightedness of the state's role in raising children, and the fixation on education, all share the same roots in neoliberalism. In examining the participants' construction of childhood and parenthood, our findings suggest compatibility between neoliberal prescriptions on self-governing individuals with paternalism in the government (see Soss et al. 2009). Previously in Indonesia, under the modernization project, the state exploited its coercive power to force certain behaviors and the adoption of lifestyles onto parts of the population that it deemed as needing change. For example, through the mobilization of the military in civil lives (Li 2000; Gaus et al. 2017). Currently, under the neoliberal era, the paternalist governance takes a subtler yet effective approach by convincing individuals and members of communities that it is in their interest to be competitive, industrial, and self-governed (Soss et al. 2009). The individualization element of neoliberalism explains the absence of the participant's reference to the community. Society is seen as a collection of individuals, and the state, rather than serving as the provider, takes on a more peripheral role as a facilitator for these individuals (Gillies 2005; Raco 2009).

More importantly, the neoliberal ideology offers the paternalistic government a new formula for governing, that is to create self-disciplining and entrepreneurial citizens who are responsible for their own welfare, a concept that's often termed "responsibilization" (Cradock 2007; Davies and Bansel 2007). Individuals are expected to be adequately responsible for their own welfare by aligning their conduct with professional prescription and capitalizing on available resources (Cradock 2007; Davies and Bansel 2007). Since children are seen as dependents, the individualization and responsibilization are imposed on parents (Wells 2011), and parents are regarded as an instrument in children's lives (Hennum 2014; Romagnoli and Wall 2012).

Once ideal childhood is defined, a prescription for how to parent soon follows (Ambert 1994). The government encouraged good parents to exhaust and sacrifice resources to advance their children's education (Holloway and Pimlott-Wilson 2014; Romagnoli and Wall 2012). Parents are expected to educate themselves and behave according to a certain standard to be considered good parents (Gillies 2005; Holloway and Pimlott-Wilson 2014; Schaefer 2010), a trend that is brewing in Indonesia, as we argue in the following section. As these parenting standards are mainly couched in middle-class bias, parents from low socio-economic classes become subject to increasing intervention and regulations aimed at correcting their parenting styles and capacity (Gillies 2005; Hennum 2014; Romagnoli and Wall 2012). Children whose parents deviate from "what policymakers would have them to do" are identified as at risk and their parents are subject to a set of change and education programs (Finerman 1995, p. 11; Romagnoli and Wall 2012; Schaefer 2010). 


\subsection{Parental Responsibility and Policy Framework}

An examination of national policies shows that the frontline providers' tendency to blame parents is an extension of the current policy paradigm. Two major laws that govern children and education in Indonesia are the Child Protection Law and the Law on National Education of 2003, both emphasize the central role of parents as the primary providers. Parents are the caretakers and the providers, while the state acts as the guarantor of services and rights. Parents are obligated to provide education for their school-aged children while the state is responsible for ensuring the availability of services (Law on National Education 2003 article 11 (2)). It is important to note the paternalistic attitude underpinning these laws, where the government is positioned as a superior entity that decides what's best for the function of children and parents, as the state's mechanism for achieving these ends. These laws also lay the foundation for subsequent policies that assume all parents, and thus all families, start from a similar point and, in doing so, the laws remove the granular socio-economic contexts in which parents operate from the policy discourse (Holloway and Pimlott-Wilson 2014; Raco 2009; Walters and Woodward 2007).

The current administration, led by Joko Widodo, takes the responsibilization of individuals and families a step further by basing the five-year policy plan (National Medium-Term Development Planning 2015-2019 or RPJMN) on the so-called "Revolusi Mental", a mental revolution centred on the idea of individual transformation. According to RPJMN, the "mental revolution" aims to transform Indonesian men and women to become not only healthy, smart, and independent individuals but also individuals who have the mental capacity to compete with other citizens of the world. The family is identified as an important space where the transformation of children should take place. Consequently, it is imperative to identify parents that are incapable of this transformational task. Regarding education, as Indonesia moves toward increasing the period of compulsory education from nine to 12 years, the policy plan identifies several barriers to full participation in the education system, of which parenting is one. The policy identifies parents' poor appreciation and understanding of the importance of both early childhood and secondary education as obstacles.

By diagnosing parents and families, the government now has a foundation to intervene in "transforming parents" through a set of strategies. The RPJMN and the subsequent medium-term strategic policies of the Ministry of Education and Culture (MoEC) put significant emphasis on standardizing and improving parenting under a platform called "family education". In fact, under the previous Minister in 2015, the MoEC launched a new mid-rank nomenclature called Directorate of Family Education. Family Education aims to increase parents' awareness about the value of education and to encourage active participation in their children's schooling. This objective resonates with the disposition to define childhood as a period reserved for formal education (Wells 2009). The program will educate parents on various child-rearing aspects including nurturing love, nutrition and health, pre-literacy education, fulfilment of children's rights and protection, prevention of deviant behaviour, and learning outcomes (Ministry of Education and Culture 2015).

The parent-as-problem model extends beyond the realm of education. Also with the RPJMN, parents are subject to assessment and re-education in regards to family planning and child protection. The strategies are targeted directly toward parents with the assumption that parents have a minimal understanding and general disregard of what qualifies as "good parenting" and a functioning family. This assumption is maintained in the current implementation of a national conditional cash transfer (CCT) program called the Family Hope Program (PKH), introduced in 2007. Elsewhere, CCT programs have been widely criticized for the inclusion of conditions, such as sending children to health check-ups and ensuring school attendance, that presuppose poor parents as irresponsible and incapable of raising their children (Ballard 2013; Molyneux 2009). In addition to these requirements, since 2014 parents of $\mathrm{PKH}$ (mothers by regulation) are also requested to attend parent education sessions called Family Development Sessions (FDSs). FDSs are designed as a supporting activity to change parents' perspectives and behaviors around managing their children's education and health. FDSs use modules on nutrition, child's education, child protection, and financial management and entrepreneurship to 
help parents use the cash responsibly (Ministry of Social Affairs 2016); this last program area echoes the participants' claim about parents' mismanagement of the cash.

The front liners' attitudes and predispositions present a broader policy significance, as they occupy an area where state and individuals meet (Durose 2007). Akin to the power of street-level bureaucrats, they have the discretion to change policy narratives into actions that directly impact individuals (Durose 2007). Findings from the present study suggest that the government now has a legion of front liners who share the same tenet on the neoliberal model of parenthood as well as an aversion to looking at the structural forces that disable parents from supporting their children. The government's efforts to pathologize parents and intervene in their parenting style will be carried out by an enthusiastic, if not zealous, group of influential figures at the community level. In addition to FDSs, the government put forward two separate bills on Family Resilience and Parenting that predominantly adhere to middle-class parenting bias. If enacted, the two bills will enable further financial and human resource mobilization to monitor, govern, and educate parents.

Studies in other countries have demonstrated that such a policy would disproportionately target poor parents and put more demand on parents who are already stretched thin in regard to time and resources. Furthermore, an ideological alliance between government and frontline providers might lessen the community's demand from the state as the spectacle is focused on parents and their lack of parenting skills (as defined by the state), rather than on the condition in which these parents must operate. At the same time, the evidence that supports parenting education is shaky at best (Aboud 2007; Casanueva et al. 2008; Schaefer 2010). This is not to say that parenting is not an essential facet of children's lives, but as others have pointed out, without substantial changes in the structural and socio-cultural context of families, intervention to change deep-seated parental perspectives and practices will not be effective (McAra 2006; Smith 2004). The circumstances of families in this study suggest the same potential results as they are increasingly marginalized and prone to external shocks due to their integration to the world market through their move to export commodities. This condition calls for immediate structural reforms. Similar conclusions been drawn from other studies, which have made calls for the better provision of food security, childcare, financial and housing support, more work options, and inclusive schools (Hennum 2014; McConnell and Llewellyn 2005; Romagnoli and Wall 2012) as well as an improved understanding among professionals around the structural issues affecting families (McCartan et al. 2018)

Findings from this study should be considered alongside a few limitations. First, most of the participants for our FGDs were also parents. Although they were invited to participate with an emphasis on sharing their experiences as public figures working with children, it was nearly impossible for them to delineate their private and public roles when it came to discussing children. Aside from a few participants who seemed to be aware of the tensions and differences between their two positions, it was difficult for most participants to engage speaking only from their professional point of view. However, these participants' double hats enriched the discussions, especially when they tried to view the questions from their two positions. Second, the findings from this study may not be generalizable to represent other districts and provinces in Indonesia. Instead, the study gives indications of the situation among predominantly agrarian communities in places where government reach is limited. Third, since this study overwhelmingly represents the perception of adults and parents who hold public roles related to children, it is critical that further studies extend the analysis by consulting parents who do not carry community responsibilities. A specific focus on understanding childhood from children's perspectives is also recommended for future studies.

\section{Conclusions}

Several studies have demonstrated the manifestation of the neoliberal project of childhood and education in the global north, especially among educators and social workers. Our research suggests that this phenomenon may be prevalent in the global south as well, as evidenced by this study in Indonesia. Our findings show a strong inclination towards the conceptualization of successful children 
as those who grow up to be economically independent adults among community providers in rural Indonesia. This is followed by a firm faith in education as a social institution with the objective of creating competent individuals who can take advantage of well-paid jobs offered by the market. As in other contexts, the individualization approach of neoliberal governance has allowed a shift in focus to individual families in rural Indonesia. Both national policies and front liners place the responsibility of children's wellbeing primarily, and almost exclusively, on parents. Consequently, children's performance is used as a proxy to assess parents and, conversely, children are categorized as "at risk" based on negative assessments of their parents.

Further, we argue that our findings show the compatibility of paternalism and neoliberalism within the construction of childhood and parenthood. Paternalistic attitudes that were prevalent under the previous regime have been maintained and even extended to be imposed on the family through the proxy of convinced frontline providers. Since children are thought to be dependent entities incapable of making rational decisions, the imposition of this paternalistic scrutiny is instead placed on the parents. The welfare or utility at stake is the children's future couched in the concept of "the best interest of the child". The government, academics, and professionals working with children are decoding, standardizing, and professionalizing parenting in alignment with the market-oriented value and education system. On the other hand, the state is seen as an enabler that provides general services and occasional stimuli while the community is virtually missing from the conversation. To the extent that it is mentioned, structural forces are either viewed as a minor factor or mediated through parents. It is the parent, or more specifically a failure to parent, that underpins childhood adversity.

The government's policy framework that increasingly positions parents as the dominant risk factor in children's lives is internalized and reproduced by front liners. This disciplining of parents is already ongoing as the government is experimenting with smaller scale parenting sessions. If the two bills that support parenting scrutiny and literacy programs are expanded, poor parents will be subject to more interventions. Although the consequences of this have yet to be researched, literature from other countries suggests that such a policy approach may not be effective in supporting parents, and that government intervention should instead focus on macrostructures that constrain parents. As this study focuses on poor families in agricultural communities who are increasingly marginalized and vulnerable to external shocks, it calls for less scrutiny on parents and more structural interventions to improve the situation where parents and children find themselves in.

Author Contributions: Conceptualization and methodology: C.S. and S.K.; data collection: C.S., S.A., P.A.; data curation: C.S.; writing—original draft preparation: C.S., S.A., P.A.; writing-review and editing: C.S., S.A., P.A., S.K.; funding: S.K.

Funding: This work and the main study was funded through a partnership between PUSKAPA and Ministry of Education and Culture, Government of Indonesia, with additional support from UNICEF and Ministry of National Development Planning (BAPPENAS).

Ethical clearance: Study protocol and instruments were reviewed and approved by Atma Jaya University's Ethical Review Board (No. 1020/III/LPPM-PM.10.05/00/2016). All participants were informed of the study purpose and provided their consent to participate in the study. We depersonalised the participant's data to maintain confidentiality and stored digital and verbatim transcript centrally in PUSKAPA.

Acknowledgments: We thank our colleagues at PUSKAPA and Yayasan Karangpuang who were involved in data collection for the main study. We also thank Chris Laugen (UBC) for his consultation on the preliminary stage of literature review and Ilana Seff (Columbia University) for her proofreading and initial round of comments.

Conflicts of Interest: The authors declare no conflict of interest.

\section{References}

Aboud, Frances E. 2007. Evaluation of an Early Childhood Parenting Programme in Rural Bangladesh. Journal of Health, Population, and Nutrition 25: 3-13. [PubMed]

Adriany, Vina. 2018. Neoliberalism and Practices of Early Childhood Education in Asia. Policy Futures in Education 16: 3-10. [CrossRef] 
Al-Samarrai, Samer, and Pedro Cerdan-Infantes. 2013. Where Did All the Money Go? Financing Basic Education in Indonesia. In Education in Indonesia. Singapore: Institute of Southeast Asian Studies, pp. 109-38.

Ambert, Anne-Marie. 1994. An International Perspective on Parenting: Social Change and Social Constructs. Journal of Marriage and Family 56: 529-43. [CrossRef]

Aspinall, Edward. 2013. A Nation in Fragments. Critical Asian Studies 45: 27-54. [CrossRef]

Ballard, Richard. 2013. Geographies of Development II: Cash Transfers and the Reinvention of Development for the Poor. Progress in Human Geography 37: 811-21. [CrossRef]

Bennett, Linda Rae. 2015. Young Sasak Mothers- ‘Tidak Manja Lagi’: Transitioning from Single Daughter to Young Married Mother in Lombok, Eastern Indonesia. In Youth Identities and Social Transformations in Modern Indonesia. Edited by Robinson Kathryn. Leiden: BRILL.

Blunt, Peter, Mark Turner, and Henrik Lindroth. 2012. Patronage, Service Delivery, and Social Justice in Indonesia. International Journal of Public Administration 35: 214-20. [CrossRef]

Boyden, Jo. 2013. 'We're Not Going to Suffer like This in the Mud': Educational Aspirations, Social Mobility and Independent Child Migration among Populations Living in Poverty. Compare: A Journal of Comparative and International Education 43: 580-600. [CrossRef]

BPS, and UNICEF. 2016. Child Marriage in Indonesia: Past Progress at a Standstill. Policy Brief. Jakarta: UNICEF.

Cammack, Mark, and Tim Heaton. 2011. Explaining the Recent Upturn in Divorce in Indonesia: Developmental Idealism and the Effect of Political Change. Asian Journal of Social Science 39: 776-96. [CrossRef]

Casanueva, Cecilia, Sandra L. Martin, Desmond K. Runyan, Richard P. Barth, and Robert H. Bradley. 2008. Parenting Services for Mothers Involved with Child Protective Services: Do They Change Maternal Parenting and Spanking Behaviors with Young Children? Children and Youth Services Review 30: 861-78. [CrossRef]

Chandra, Alexander. 2011. A Dirty Word? Neo-Liberalism in Indonesia's Foreign Economic Policies. Trade Knowledge Network. Winnipeg: International Institute for Sustainable Development.

Cradock, Gerald. 2007. The Responsibility Dance: Creating Neoliberal Children. Childhood 14: 153-72. [CrossRef]

Crivello, Gina, and Jo Boyden. 2012. On Childhood and Risk: An Exploration of Children's Everyday Experiences in Rural Peru. Children E Society 28: 380-91. [CrossRef]

Davies, Brownyn, and Peter Bansel. 2007. Neoliberalism and Education. International Journal of Qualitative Studies in Education 16: 883-86. [CrossRef]

Durose, Catherine. 2007. Beyond 'Street Level Bureaucrats': Re-interpreting the Role of Front Line Public Sector Workers. Critical Policy Studies 1: 217-34. [CrossRef]

Finerman, Ruthbeth. 1995. 'Parental Incompetence' and 'Selective Neglect': Blaming the Victim in Child Survival. Social Science E Medicine, Guilt, Blame and Shame: Responsibility in Health and Sickness 40: 5-13. [CrossRef]

Gaus, Nurdiana, Sultan Sultan, and Muhammad Basri. 2017. State Bureaucracy in Indonesia and Its Reforms: An Overview. International Journal of Public Administration 40: 658-69. [CrossRef]

Gellert, Paul K. 2015. Optimism and Education: The New Ideology of Development in Indonesia. Journal of Contemporary Asia 45: 371-93. [CrossRef]

Gibbon, Peter, Benoit Daviron, and Stephanie Barral. 2014. Lineages of Paternalism: An Introduction. Journal of Agrarian Change 14: 165-89. [CrossRef]

Gillies, Val. 2005. Meeting Parents' Needs? Discourses of 'Support' and 'Inclusion' in Family Policy. Critical Social Policy 25: 70-90. [CrossRef]

Guest, Greg, Kathleen M. MacQueen, and Emily E. Namey. 2011. Applied Thematic Analysis. London: SAGE.

Hadiz, Vedi R. 2004. Indonesian Local Party Politics. Critical Asian Studies 36: 615-36. [CrossRef]

Harvey, David. 2007. A Brief History of Neoliberalism. Cary: Oxford University Press.

Hendriks, Carolyn M. 2007. Praxis Stories: Experiencing Interpretive Policy Research. Critical Policy Studies 1: 278-300. [CrossRef]

Hennum, Nicole. 2014. Developing Child-Centered Social Policies: When Professionalism Takes Over. Social Sciences 3: 441-59. [CrossRef]

Heryanto, Ariel. 1995. Language of Development and Development of Language: The Case of Indonesia. Pacific Linguistics 86. Canberra: Department of Linguistics, Research School of Pacific and Asian Studies, Australian National University.

Holloway, Sarah L., and Helena Pimlott-Wilson. 2011. The Politics of Aspiration: Neo-Liberal Education Policy, 'Low' Parental Aspirations, and Primary School Extended Services in Disadvantaged Communities. Children's Geographies 9: 79-94. [CrossRef] 
Holloway, Sarah L, and Helena Pimlott-Wilson. 2014. 'Any Advice Is Welcome Isn't It?': Neoliberal Parenting Education, Local Mothering Cultures, and Social Class. Environment and Planning A: Economy and Space 46: 94-111. [CrossRef]

Hyslop, Ian, Emily Keddell, Ian Hyslop, and Emily Keddell. 2018. Outing the Elephants: Exploring a New Paradigm for Child Protection Social Work. Social Sciences 7: 105. [CrossRef]

James, Allison. 1997. Constructing and Reconstructing Childhood: Contemporary Issues in the Sociological Study of Childhood. Hove: Psychology Press.

Kathryn, Robinson, ed. 2015. Youth Identities and Social Transformations in Modern Indonesia. Leiden: BRILL.

Kitley, Philip. 1999. Pancasila in the Minor Key: TVRI's 'Si Unyil' Models the Child. Indonesia 68: 129. [CrossRef]

Li, Tania Murray. 1999. Compromising Power: Development, Culture, and Rule in Indonesia. Cultural Anthropology 14: 295-322. [CrossRef]

Li, Tania Murray. 2000. Articulating Indigenous Identity in Indonesia: Resource Politics and the Tribal Slot. Comparative Studies in Society and History 42: 149-79.

Li, Tania Murray. 2005. Beyond 'the State' and Failed Schemes. American Anthropologist 107: 383-94. [CrossRef]

Liddle, R. William. 1996. Indonesia: Suharto's Tightening Grip. Journal of Democracy 7: 58-72. [CrossRef]

Ling, Minhua. 2015. 'Bad Students Go to Vocational Schools!': Education, Social Reproduction and Migrant Youth in Urban China. The China Journal 73: 108-31. [CrossRef]

McAra, Lesley. 2006. Welfare in Crisis? Key Developments in Scottish Youth Justice. In Comparative Youth Justice. London: Sage, pp. 127-45.

Mccafferty, Patricia. 2010. Forging a 'Neoliberal Pedagogy': The 'Enterprising Education' Agenda in Schools. Critical Social Policy 30: 541-63. [CrossRef]

McCartan, Claire, Aine Morrison, Lisa Bunting, Gavin Davidson, Jackie Mcllroy, Claire McCartan, Aine Morrison, Lisa Bunting, Gavin Davidson, and Jackie Mcllroy. 2018. Stripping the Wallpaper of Practice: Empowering Social Workers to Tackle Poverty. Social Sciences 7: 193. [CrossRef]

McConnell, David, and Gwynnyth Llewellyn. 2005. Social Inequality, 'the Deviant Parent' and Child Protection Practice. Australian Journal of Social Issues 40: 553-66. [CrossRef]

Ministry of Education and Culture. 2015. Strategic Plan of Ministry of Education and Culture 2015-2019; Jakarta: Ministry of Education and Culture Republic of Indonesia.

Ministry of Social Affairs. 2016. Buku Pedoman Pelaksanaan Program Keluarga Harapan 2016/Implementing Manual for Family Hope Program 2016; Jakarta: Ministry of Social Affairs.

Molyneux, Maxine. 2009. Conditional Cash Transfers: A Pathway to Women's Empowerment? Pathways Brief 5. London: DFID.

Moser, Sarah. 2010. Creating Citizens through Play: The Role of Leisure in Indonesian Nation-Building. Social E Cultural Geography 11: 53-73. [CrossRef]

Newberry, Jan. 2010. The Global Child and Non-Governmental Governance of the Family in Post-Suharto Indonesia. Economy and Society 39: 403-26. [CrossRef]

Newberry, Jan. 2014a. Class Mobil: Circulation of Children in the Making of Middle Indonesia. In In Search of Middle Indonesia: Middle Classes in Provincial Towns. Edited by Gerry van Klinken and Ward Berenschot. Verhandelingen van Het Koninklijk Instituut Voor Taal-, Land En Volkenkunde. Boston: Brill.

Newberry, Jan. 2014b. Women Against Children: Early Childhood Education and the Domestic Community in Post-Suharto Indonesia. TRaNS: Trans-Regional and-National Studies of Southeast Asia 2: 271-91. [CrossRef]

O'Kane, Claire, and Sofni Lubis. 2016. Alternative Child Care and Deinstitutionalisation. Jakarta: SOS Children Village \& European Commission. Available online: https:/ /www.celcis.org/files/2114/8482/3678/CELCIS_ __Indonesia-_towards-right-care-for-children-alternative-care-and-deinstitutionalisation-2017.pdf (accessed on 9 October 2017).

Parker, Lyn. 2002. The Subjectification of Citizenship: Student Interpretations of School Teachings in Bali. Asian Studies Review 26: 3-37. [CrossRef]

Pepinsky, Thomas B., Jan H. Pierskalla, and Audrey Sacks. 2017. Bureaucracy and Service Delivery. Annual Review of Political Science 20: 249-68. [CrossRef]

Peterson, Elizabeth R., Christine M. Rubie-Davies, Margaret J. Elley-Brown, Deborah A. Widdowson, Robyn S. Dixon, and S. Earl Irving. 2011. Who Is to Blame? Students, Teachers and Parents Views on Who Is Responsible for Student Achievement. Research in Education 86: 1-12. [CrossRef] 
Pye, Oliver, Ramlah Daud, Yuyun Harmono, and Tatat. 2012. Precarious Lives: Transnational Biographies of Migrant Oil Palm Workers: Precarious Lives: Migrant Palm Oil Workers. Asia Pacific Viewpoint 53: 330-42. [CrossRef]

Qvortrup, Jens. 2008. Childhood and Politics. In Citizenship Education in Society: A Challenge for the Nordic Countries. Trondheim: Norwegian University for Science and Technology.

Raco, Mike. 2009. From Expectations to Aspirations: State Modernisation, Urban Policy, and the Existential Politics of Welfare in the UK. Political Geography 28: 436-44. [CrossRef]

Reay, Diane. 2004. 'It's All Becoming a Habitus': Beyond the Habitual Use of Habitus in Educational Research. British Journal of Sociology of Education 25: 431-44. [CrossRef]

Robison, Richard, and Vedi Hadiz. 2004. Reorganising Power in Indonesia: The Politics of Oligarchy in an Age of Markets. Abingdon-on-Thames: Routledge.

Romagnoli, Amy, and Glenda Wall. 2012. 'I Know I'm a Good Mom': Young, Low-Income Mothers' Experiences with Risk Perception, Intensive Parenting Ideology and Parenting Education Programmes. Health, Risk $\mathcal{E}$ Society 14: 273-89. [CrossRef]

Russell, Mary, Barbara Harris, and Annemarie Gockel. 2008. Parenting in Poverty: Perspectives of High-Risk Parents. Journal of Children and Poverty 14: 83-98. [CrossRef]

Schaefer, Tali. 2010. Saving Children or Blaming Parents-Lessons from Mandated Parenting Classes. Columbia Journal of Gender and Law 19: 491.

Shiraishi, Saya. 1996. The Birth of Father and Mother in the Indonesian Classroom. Southeast Asian Studies 34: 15.

Shiraishi, Saya. 1997. Young Heroes: The Indonesian Family in Politics. Chapel Hill: SEAP Publications.

Shiraishi, Takashi. 2006. Technocracy in Indonesia: A Preliminary Analysis. Tokyo: The Research Institute of Economy, Trade, and Industry (RIETI).

Silalahi, Ronald Maraden Parlindungan, Njaju Jenny Malik, and E. Mulyajati. 2018. Reconstructing Joko Widodo's National Education Ideology: A Critical Discourse Analysis on the Policies in Indonesia. In Cultural Dynamics in a Globalized World. London: Routledge.

Smith, David John. 2004. Parenting and Delinquency at Ages 12 to 15. Edinburgh: University of Edinburgh, Centre for Law and Society.

Soss, Joe, Richard C. Fording, and Sanford F. Schram. 2009. Governing the Poor: The Rise of the Neoliberal Paternalist State. In Proceedings of the 2009 Annual Meeting of the American Political Science Association, Toronto, ON, Canada, 1-4 September; p. 33.

Suharti, Suharti. 2013. Trends in Education in Indonesia. In Education in Indonesia. Singapore: Institute of Southeast Asian Studies (ISEAS).

Sumner, Cate, and Santi Kusumaningrum. 2014. Indonesia's Missing Millions: A Baseline Study on Legal Identity. Jakarta: Australian Indonesia Partnership for Justice.

Suryadarma, Daniel, and Gavin W. Jones. 2013. Education in Indonesia. Singapore: Institute of Southeast Asian Studies.

Tesar, Marek, Sophia Rodriguez, and David W. Kupferman. 2016. Philosophy and Pedagogy of Childhood, Adolescence and Youth. Global Studies of Childhood 6: 169-76. [CrossRef]

Titaley, Christiana R., Cynthia L. Hunter, Michael J. Dibley, and Peter Heywood. 2010. Why Do Some Women Still Prefer Traditional Birth Attendants and Home Delivery?: A Qualitative Study on Delivery Care Services in West Java Province, Indonesia. BMC Pregnancy and Childbirth 10: 43. [CrossRef]

Tomanović, Smiljka. 2004. Family Habitus as the Cultural Context for Childhood. Childhood 11: 339-60. [CrossRef]

UNICEF. 2017. SDG Baseline Report on Children in Indonesia. Jakarta, Indonesia. Available online: http:/ / www.developmentpathways.co.uk/resources/wp-content/uploads/2017/08/SDG_Baseline_

Report_on_Children_in_Indonesia1-1.pdf (accessed on 29 August 2017).

Walters, Reece, and Rona Woodward. 2007. Punishing 'Poor Parents': 'Respect', 'Responsibility' and Parenting Orders in Scotland. Youth Justice 7: 5-20. [CrossRef]

Warouw, Johannes Nicolaas. 2004. Assuming Modernity: Migrant Industrial Workers in Tangerang, Indonesia. Ph.D. thesis, Australian National University, Canberra, Australia. Available online: https:/ / openresearchrepository.anu.edu.au/handle/1885/9954 (accessed on 16 March 2018).

Wells, Karen. 2009. Childhood in a Global Perspective. Hoboken: John Wiley \& Sons.

Wells, Karen. 2011. The Politics of Life: Governing Childhood. Global Studies of Childhood 1: 15-25. [CrossRef] 
White, Ben. 2005. Between Apologia and Critical Discourse: Agrarian Transitions and Scholarly Engagement in Indonesia. In Social Science and Power in Indonesia. Edited by Vedi R. Hadiz and Daniel Dhakidae. Jakarta: Equinox Publishing.

White, Ben. 2012. Changing Childhoods: Javanese Village Children in Three Generations. Journal of Agrarian Change 12: 81-97. [CrossRef]

Yanow, Dvora. 2000. Conducting Interpretive Policy Analysis. London: SAGE.

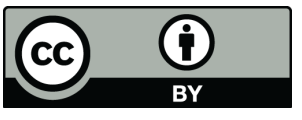

(c) 2019 by the authors. Licensee MDPI, Basel, Switzerland. This article is an open access article distributed under the terms and conditions of the Creative Commons Attribution (CC BY) license (http:/ / creativecommons.org/licenses/by/4.0/). 